\title{
CONTRIBUTION TO DIFFERENTIAL DIAGNOSTICS OF GRANULOMATOUS LESIONS IN LUNG TISSUE
}

\author{
Jaroslav Horáček, Vladimír Hořava
}

Department of Pathology, Medico - Social Faculty of Ostrava University, 70386 Ostrava, Czech Republic

Received: September 20, 2002

Key words: Lung / Granulomatous lesion / Diagnostics

Etiopathogenesis of pulmonary granulomatous lesions can be very varied. Pathologists find pulmonary granulomatous lesions in autopsies frequently. Diagnostics of pulmonary granulomatous lesions is based on anamnesis data, clinical examinations and morphological changes. In some cases, especially in long-term ill patients, morphological finding remains the only way to explain the case. We provide a description of an incidental autoptic finding of chronic granulomatous lesion in lung tissue in a man aged 81. Histopathological examination proved aspired granules of maize starch. Aspired granules triggered lesion of granulomatous character.

At microscopic examination vegetable particles were defined to be maize starch. Granules of maize starch, which are a part of artificial nutrition labelled Caglusal, may have caused granulomatous lesion in our case.

\section{INTRODUCTION}

Though granulomatous lesions are found in lung tissue quite often, their etiopathogenesis raises hesitancy during autopsies and biopsies. Granulomatous lesions and granulatoses were dealt with by many authors both from abroad ${ }^{1-3}$ and our country ${ }^{4-10}$.

The authors usually dealt with specific inflammations corresponding to tuberculosis or sarcoidosis, granulomatous lesions of tumor nature, opportune infections in primary and secondary immunodeficiencies predominantly of mycotic origin, lesions associated with congenital enzymatic defects and reactions to foreign material. Granulomatous processes of Wegener's granulomatosis and allergic granulomatoses of ChurgStrauss syndrome are less frequent. Granulomatous processes inspired by Langerhans cells were described by Hayashi not long ago ${ }^{11}$.

In our study we were interested in non-tumorous granulomatous lesions caused by aspiration. The following vegetable substances have been mentioned in recent literature: cellulose, vegetable particles of oat, fruits with spiny surface, rests of parasite echinococcal cystic membranes. Some granulomas represent treatment consequences of pneumocystic pneumonias with dystrophic process of calcification in AIDS $12,13,14,15,16$.

\section{OBSERVATION}

A pensioner aged 81, a transport supervisor in his career, with no significant family anamnesis, suffered from chronic ischemic heart disease, hypertension of the third degree, nephrolithiasis and chronic inflammation of stomach. Three years before his death he underwent aorta-coronary by-pass operation. $\mathrm{He}$ also experienced two attacks of cerebral apoplexy resulting in paralysis of right upper extremity. X-ray stomach examination using a contrast medium was indicated in this patient for three times. X-ray of his lungs showed infiltration on his right side basal. Neither laboratory blood examination, nor biochemical examination showed any pathological values. No immunological examination was done. Treatment of the patient, backdated from his medical report, was focused on hypertension and ischemic heart disease. The following medicine was prescribed: Droperidol, Furosemid, Thioridazin, Spophyllin, Isoptin, Anopyrin, Heparin and Ambroxol.

Having suffered from pain in right side of chest and breathlessness lasting for a few days, the patient was admitted to pulmonary department. After transporting to intensive care unit the patient died of left side heart failure.

At autopsy heart attack was proved to be the reason of the patient's death. A tumor-like structure was found in the lower lobe of his right lung under pleura. The structure was of grayish color, tough consistency, not sharply cut. The size of the structure was $4 \times 3,5 \times 3,5 \mathrm{~cm}$. This incidental finding was identical with that from $\mathrm{X}$-ray of lungs mentioned above. 
Microscopic examination showed granulomatous lesion with vague margins. Its histological structure resulted from reaction of giant cells, which surrounded oval or round granules. Cellular walls of granules were thickened and corresponded to vegetable glykokalyx with apparent internal septal structure. Some granules inspired histiocytarn reaction accompanied with multinuclear cells with many nuclei, corresponding to giant cells surrounding foreign material (Fig. 1). Older lesions were surrounded with hyalinized collagen fibres. Inflammatory lymphocyte and plasmocyte reactions were not significant in periphery.

Vegetable particles were found only in some parts of granulomatous lesions. They were totally resorbed by multinuclear histiocytes or regressively changed, thus producing granular dissemination with nuclear debris. Palisade arrangement of fibrohistiocytes surrounding single granules was less frequent (Fig. 2).

In polarised light positivity in external contour of vegetable particles of granules was found. Internal septal structure of particles was of isomorphic character.

In special PAS staining method positivity in glykokalyx was found. In Grocott s method with silver impregnation significant positivity of cellular walls was proved. In green trichrome staining method significant positivity of vegetable structures was found.

We used results achieved from special staining methods and histopathological comparisons to two similar cases withdrawn from our database (which were from the microscopic point of view identical) to identify etiopathologenesis of our granulomatous lesions as precisely as possible. We concluded that lesion in our study was the consequence of aspiration of maize starch, a part of artificial nutrition labelled Caglusal. Taking into account long-term character of the patient's illness, the probability of aspiration of artificial nutrition is definitively very high.

\section{DISCUSSION}

Non-tumorous structures of lung granulomatous lesions can be of various etiologies. Many granulomas are from the etiopathogenetic point of view very difficult to classify.

Bronchopneumonias caused by aspiration were the topic of lectures given by Viklický at the symposium of pathologists at Luhačovice in 1970 (ref. ${ }^{17}$ ). The author described miliar changes on lungs caused by aspiration of pulses. Nevinsen described lung sarkoid-like granulomatous lesion, consequence of inhalation of cosmetic aerosols, in $1965^{18}$. Wright described similar finding in 1981 and so did Cain later on ${ }^{19}{ }^{20}$. Both authors were interested in histopathologic analyses of granulomas. Papers published in our country appeared only after introducing bronchography which used composition of iodine oil and talk labelled Lipiodol ${ }^{21}$.

Johnston and Weisman studied ultrastructure of granulomas caused by aspiration of starch granules in
1971 (ref. ${ }^{22}$ ). Crome and Valentine described 2 cases of pulmonary nodular granulamatosis caused by inhalation of vegetable particles in 1962 (ref. ${ }^{23}$ ). Pešek published a very interesting finding of granulomatous change on bronchial mucosa, consequence of aspiration of a ferrous sulphate tablet in a man, aged $74\left(\right.$ ref. $\left.{ }^{24}\right)$.

Aspired vegetable particles are usually whole beans or peas, digested vegetable particles of food, or stomach contents. In our study we concluded that he finding was manufactured vegetable structure, part of artificial nutrition.

Although aspired foreign material inspires production of granulomatous lesion quite frequently, the original agent is difficult to identify and it often remains unclear ${ }^{25}$.

Published study results show that tracheobronchial amyloidosis and bronchogene carcinoma are occasionally able to imitate aspiration of foreign material ${ }^{26,27}$.

\section{ACKNOWLEDGEMENTS}

The paper was supported by the grant-project NJ 65783/2001 IGA MZ of Czech Republic. Special acknowledgements belong to prof. MUDr. Rostislav Kod'ousek, DrSc. for consultation.

\section{REFERENCES}

1. Dunnil MS (1991) Pulmonary granulomatosis and angiitis. Histopathology 19, 297-301.

2. Fienberg R (1981) The Protracted Superficial Phenomenon in Pathergic (Wegener s) Granulomatosis. Human Pathology 12 (5), 458-467.

3. Mark JM, Matsubara O, Tan-liu NS, Fienberg R (1988) The Pulmonary Biopsy in the Early Diagnosis of Wegener s (Pathergic) Granulomatosis: A Study Based on 35 Open Lung Biopsies. Human Pathology 19 (9), 1065-1071.

4. Mildeová E (1971) Komplikace bronchografie při použití dionosil aqueous. Čs. Patol. 7(3), 157-164.

5. Levinský L, Macholda F (1971) Fifth international conference on sarcoidosis. UK Praha.

6. Vortel V, Plachý V, Benešová D (1975) Význam plísní v morfogeneze plicních změn při chronické granulomatóze dětského věku. Čs.Patol. 11(4), 180-186.

7. Miřejovský P, Spáčilová M (1975) Bronchocentrická plicní granulomatóza. Čs. Patol. 11(7), 187-192.

8. Fakan F (1977) Chronická granulomatóza dětského věku. Čs. Patol. 13(3), 101-107.

9. Dušek J, Kod'ousek R, Myšák J, Říha V, Alušík Š, Hauftová D (1981) Diseminovaná infekce vyvolaná mycobacterium avium intracellulare. Čs.Patol. 17(2), 101-108.

10. Horáček J, Dědič K (1990) Příspěvek k výskytu granulomatózních procesů v plicích. Čs.Patol. 26(2), 97-101.

11. Hayashi T, Rush WL, Travis WD, Liotta LA, Stetler-Stevenson WG, Ferrans VJ (1997) Immunohistochemical Study of Matrix Metalloproteinases and Their Tissue Inhibitors in Pulmonary Langerhans Cell Granulomatosis. Arch. Pathol. Lab. Med. 121, 930-937.

12. Diaz-Ruiz MJ, Gallardo X, Castaner E, Mata JM, Catala J, Ferreres JC (1999) Cellulose granulomatosis of the lungs. Eur. Radiol. 9(6), 1203-1204.

13. Qureshi RA, Soorae AE (2001) Foreign body in tracheal bronchus simulating bronchogenic cancer. Eur. J. Cardiothorac. Surg. 20(3), 639-641. 


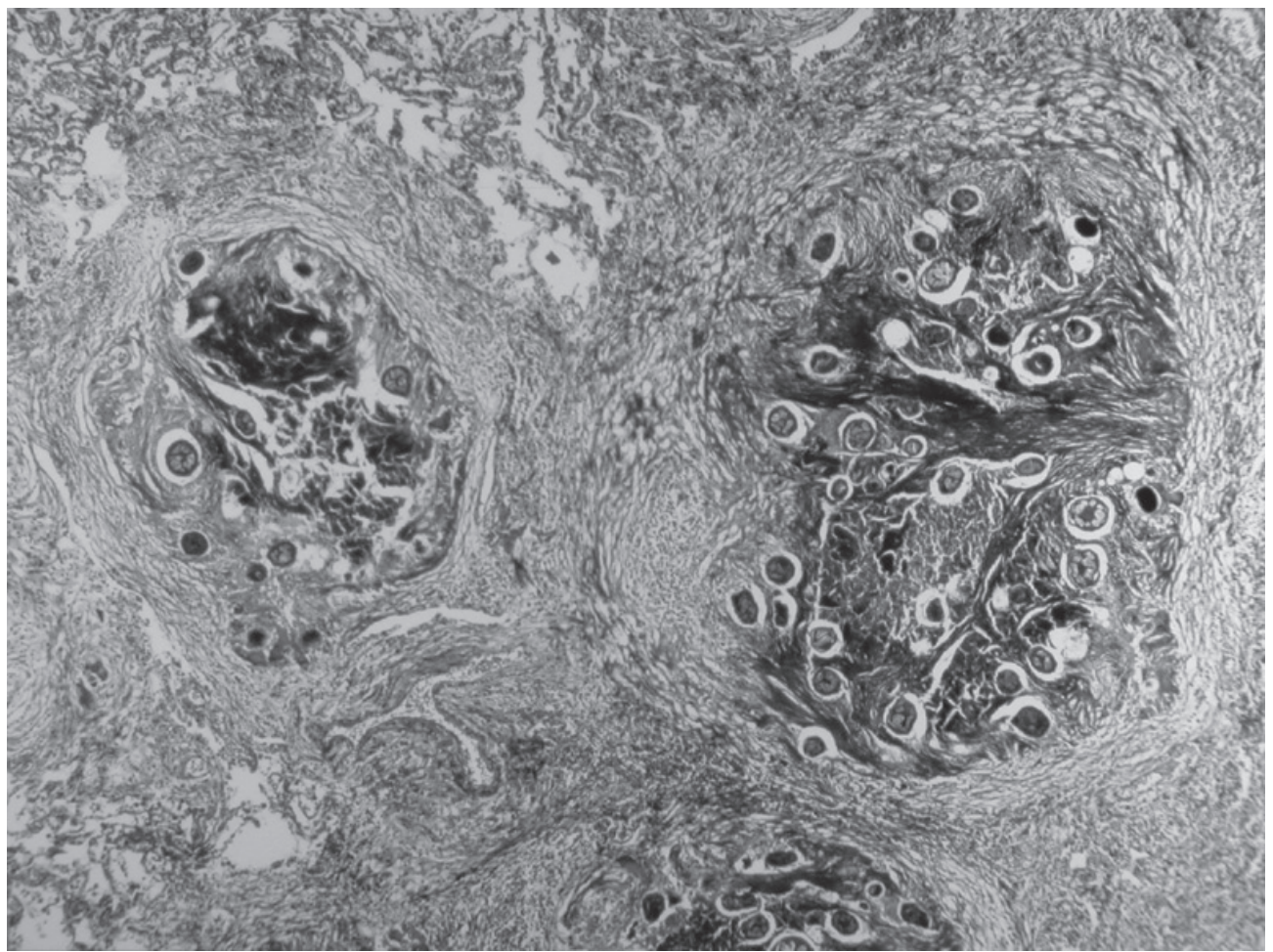

Fig. 1. Granulomatous reaction in the lung tissue (green trichrome, $\times 100$ ).

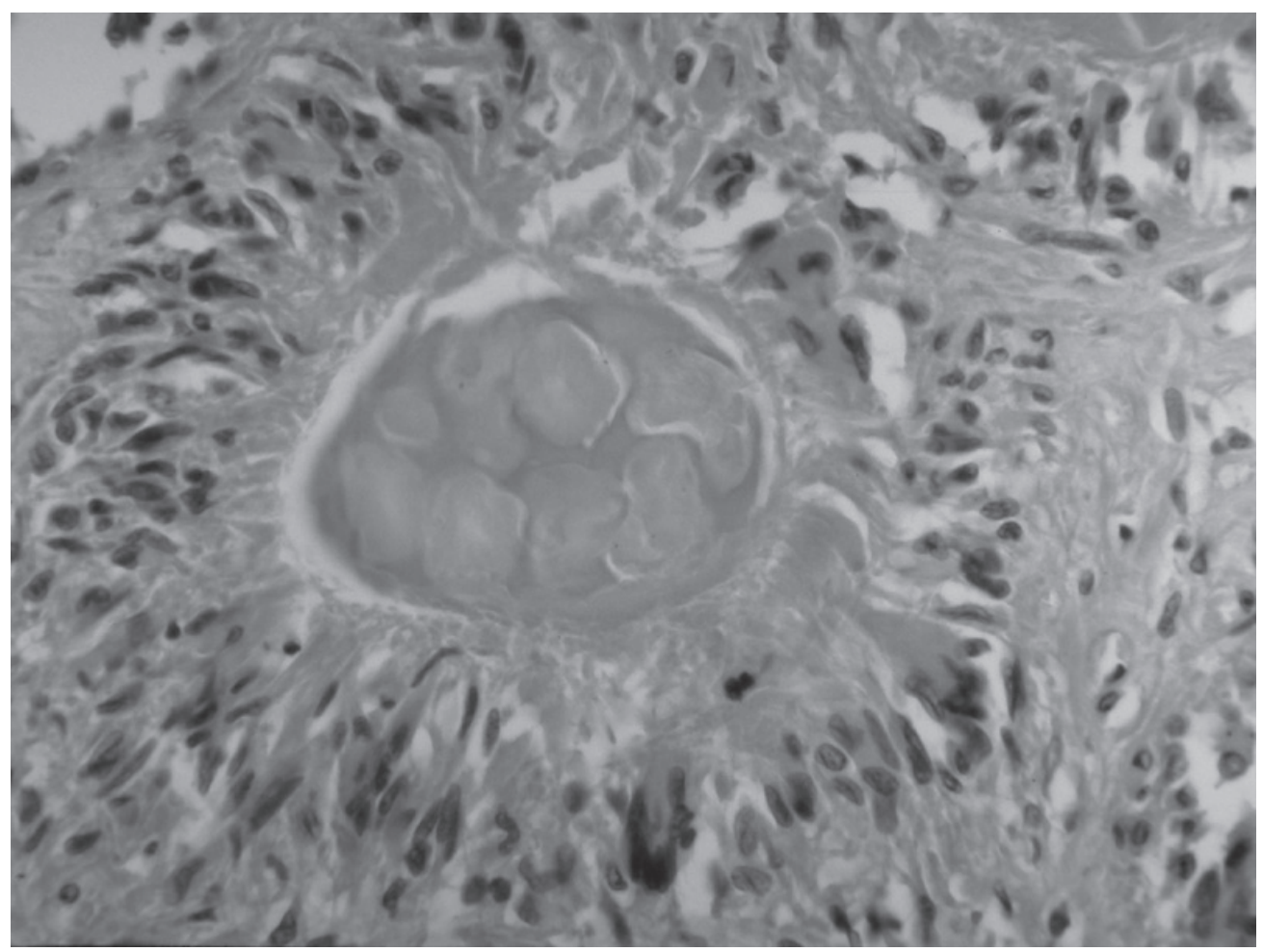

Fig. 2. The palisade structure of fibrohistiocytes around starch granules (PAS, $\times 200)$. 
14. Raos M, Bumber Z, Kovac K (2001) A bronchial polyp and foreign body in an adolescent. Lijec. Vjesn. 123(7-8), 177-178.

15. Hatem K, Dalenda N, Hela H, Mohamed F (2000) An unusua bronchial foreign body: an hydatid cyst membrane. Tunis. Med. 78(2), 143-145.

16. Bontikous S, Amthor MJ (2000) Pulmonary microcalcification with miliary foreign-body granulomas. Residuals of cured Pneumocystis carinii pneumonia in AIDS. Pathologe 21(3), 247-249.

17. Viklický V (1970) Aspirační bronchopneumonie. Sjezd patologů, červen, Luhačovice.

18. Nevins MA, Stechel GH, Fishman SI, Schwartz G, Allen AC (1965) Pulmonary Granulomatosis. JAMA 193(4), 266-271.

19. Wright JL, Cockcroft DW (1981) Lung Disease due to Abuse of Hairspray. Arch. Pathol. Lab. Med. 105, 363-366.

20. Cain H (1981) Granulome und Granulomatosen. Pathologe 2, 65-71.

21. Záková N, Svoboda M (1964) Morfologické změny v plicích po bronchografiích jódovaným olejem (lipiodolem) s přidáním talku. Cas. Lék. čes. 3(12), 311-312.
22. Johnston WH, Waisman J (1971) Pulmonary Corn Starch Granulomas in a Drug User. Arch. Path. 92, 196-202.

23. Crome L, Valentine JC (1962) Pulmonary nodular granulomatosis caused by inhaled vegetable particles. J. Clin. Path. 15, 21-25.

24. Pešek M, Eliasová B, Brůha F, Novák K, Mukenšnábl P (1998) Následky aspirace tablety síranu železa. Stud. Pneumol. Phthiseol. 58(1), 34-36.

25. Barben J, Berkowitz RG, Kemp A, Massie J (2000) Bronchial granuloma - where s the foreign body? Int. J. Pediatr. Otorhinolaryngol. 53(3), 215-219.

26. Vajda K, Meszaros I, Morocz E, Strausz J (2002) Tumor-like tracheal and lung diseases in biopsy samples. Orv. Hetil. 143(6), 295-298.

27. Qureshi RA, Soorae AS (2001) Foreign body in tracheal bronchus simulating bronchogenic cancer. Eur. J. Cardiothorac. Surg. 20(3), 639-641. 